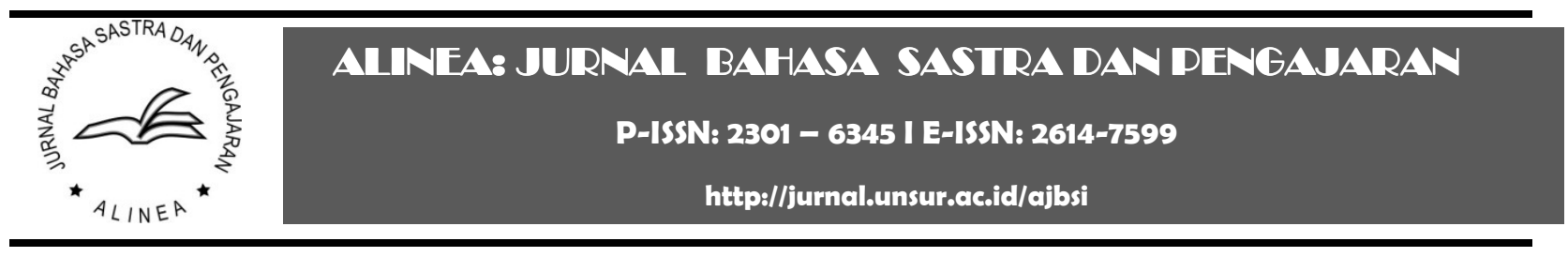

\title{
IMPLEMENTASI MODEL DISCOVERY LEARNING DALAM MENEMUKAN REALITAS KEHIDUPAN DALAM BIOGRAFI CHAIRIL ANWAR
}

\author{
Ane Ratna Octariana \\ Universitas Suryakancana, Cianjur
}

Riwayat artikel:

Dikirim: 16 Oktober 2018

Direvisi: 17 April 2019

Diterima: 8 Oktober 2019

Diterbitkan: 30 Oktober 2019

Katakunci:

Biografi

Chairil Anwar

Discovery Learning

Alamat surat

ratna_ane@yahoo.co.id

\begin{abstract}
Abstrak:
Artikel ini membahas penerapan model discovery learning dalam pembelajaran menemukan realitas kehidupan dalam sebuah biografi. Metode yang digunakan dalam penelitian ini adalah metode deskriptif. Subjek penelitian ini adalah 32 siswa kelas X IPS 5 SMA Pasundan 1 Cianjur. Pengumpulan data dilakukan dengan angket dan hasil kerja siswa. Hasil kemampuan siswa dalam menemukan realitas kehidupan dianalisis dengan teknik analisis isi. Hasil penelitian menunjukkan bahwa kemampuan siswa dalam menemukan realitas kehidupan dalam biografi Chairil Anwar dengan model discovery learning sudah baik.
\end{abstract}

\section{Abstract:}

This article discusses the application of discovery learning model in learning of finding reality of life in a biography. The method used in this research was descriptive method. The subjects of this study were 32 students of class X IPS 5 of SMA Pasundan 1 Cianjur. Data were collected from questionnaire and students' work. The results of students' work in finding the reality of life were analyzed by content analysis techniques. The results show that the ability of students to find the reality of life in Chairil Anwar's biography with the discovery learning model was good.

\section{PENDAHULUAN}

Proses pembelajaran di dalam kelas diarahkan kepada kemampuan siswa untuk menghafal informasi; otak siswa dipaksa untuk mengingat dan menimbun berbagai informasi tanpa dituntut untuk memahami informasi yang diingatnya itu untuk menghubungkannya dengan kehidupan sehari-hari (Sanjaya).

Keberhasilan proses pembelajaran tidak terlepas dari kemampuan guru mengembangkan model-model pembelajaran yang berorientasi pada peningkatan intensitas keterlibatan siswa secara efektif di dalam proses pembelajaran. Pengembangan model pembelajaran yang tepat pada dasarnya bertujuan untuk menciptakan kondisi pembelajaran yang memungkinkan siswa dapat belajar secara aktif dan menyenangkan sehingga siswa dapat meraih hasil belajar dan prestasi yang optimal.

Salah satu model pembelajaran yang dapat digunakan oleh guru adalah model pembelajaran melalui penemuan atau discovery learning. Dalam penerapan model ini guru menekankan pentingnya pemahaman stuktur atau ide-ide penting terhadap suatu disiplin ilmu, melalui keterlibatan siswa secara aktif dalam pembelajaran.

Niki Agustina dalam penelitiannya menjelaskan bahwa penggunaan discovery learning dalam pembelajaran dapat meningkatkan hasil belajar (Agustina). Begitu juga hasil penelitian Fidya Novita dkk. menjelaskan bahwa model 
discovery learning dapat meningkatkan hasil belajar peserta didik (Novita et al.).

Penelitian lain menemukan bahwa "showed a positive influence of the usage of discovery learning model to the mathematics creative thinking abilities of students. Students' learning activities through discovery model was included in active level" (Muslim). Discovery learning juga "mampu menumbuhkan rasa kritis dan menjadikan pembelajaran bersifat analitis" (Mahdi et al.). Sementara Laila dkk. 'menunjukkan ada perbedaan antara model pembelajaran discovery learning dan model konvensional' (Laila and Widodo Budhi).

Bukan hanya siswa yang harus mengetahui dan memperoleh pengalaman, guru juga perlu memperhatikan beberapa hal agar apa yang akan diajarkan kepada siswa dapat tercapai. Salah satunya dengan memperhatikan rencana pelaksanaan pembelajaran (RPP), serta pemilihan pendekatan pembelajaran, karena hal tersebut sangat berpengaruh dalam pemerolehan pemahaman siswa dalam proses pembelajaran.

Pemilihan pendekatan dapat disesuaikan dengan materi pembelajaran, hal tersebut dapat memudahkan guru dalam mengajarkan pembelajaran menemukan realitas kehidupan pada siswa, tetapi guru juga harus menyesuaikan dengan alokasi waktunya agar proses pembelajaran dapat berjalan secara efisien dan siswa dapat memahami mengenai materi yang guru sampaikan. Guru juga dapat menyiasati dengan menggunakan media seperti menggunakan biografi sebagai media pembelajaran.

Dengan membaca biografi seseorang, siswa akan mendapat gambaran dan pengetahuan mengenai perjalanan hidup dan perjuangan hidup seseorang baik tokoh maupun sastrawan yang menginspirasi, sehingga siswa akan lebih termotivasi dalam menemukan realitas kehidupan yang dialami oleh tokoh biografi tersebut. Sebagai pembelajaran awal menemukan realitas kehidupan, guru dapat membatasi biografi yang guru pilih dalam pembelajaran biografi Chairil Anwar guru hanya memfokuskan tiga sikap dan perilaku yang berhubungan dengan diri sendiri, keluarga, serta masyarakat dan bangsa. Dengan pembatasan seperti itu siswa akan mudah menemukan realitas kehidupan dan karya yang dihasilkan siswa akan mudah dipahami oleh guru. Ketika siswa sudah memahami dan mampu menemukan realitas kehidupan dengan baik dan benar maka siswa boleh mempersentasikan hasil dari kelompok masing-masing di depan kelas.

Istilah discovery learning ini menekankan pentingnya pemahaman stuktur atau ide-ide penting terhadap suatu disiplin ilmu, melalui keterlibatan siswa secara aktif dalam proses pembelajaran. Pembelajaran penemuan merupakan salah satu model pembelajaran yang digunakan dalam pendekatan konstruktivis modern. Pada pembelajaran penemuan, peserta didik didorong untuk belajar sendiri melalui keterlibatan aktif dengan gurunya.

Dalam proses pembelajaran, telah mengubah peran guru dan siswa. Peran guru telah berubah dari: (1) sebagai penyampai pengetahuan, sumber utama informasi, ahli fasilitator pembelajaran, pelatih, kolabolator, dan mitra belajar; (2) dari mengendalikan dan mengarahkan semua aspek pembelajaran, menjadi lebih banyak memberikan alternatif dan tanggung jawab kepada setiap siswa dalam proses pembelajaran. Sementara itu, peran siswa dalam pembelajaran telah mengalami perubahan juga, yaitu (1) dari penerima informasi yang pasif menjadi partisipan aktif dalam proses pembelajaran, (2) dari mengungkapkan kembali pengetahuan menghasilkan dari berbagai pengetahuan (3) dari pembelajaran sebagai aktivitas individual menjadi pembelajaran berkolaboratif dengan siswa lain.

Karakter dimaknai sebagai cara berfikir dan berperilaku yang khas tiap individu untuk hidup dan berkerja sama, baik dalam lingkungan keluarga, masayarakat,bangsa dan Negara. Karakter tidak sekedar sikap yang dicerminkan oleh perilaku, tetapi juga terkait 
dengan motif yang melandasi suatu sikap. Karakter dapat dianggap sebagai nilai-nilai perilaku manusia yang berhubungan dengan Tuhan Yang Maha Esa, diri sendiri, sesama manusia, lingkungan dan kebangsaan yang terwujud dalam fikiran, sikap, perasana, perkataan, dan perbuatan berdasarkan normanorma agama, hukum, tata karma, budaya, adat istiadat, dan estetika. Dalam kaitan ini sikap dan perilaku mengandung hubungannya dengan diri sendiri, keluarga, serta masyarakat dan bangsa.

Siapa yang mendengar nama chairil anwar pasti fikirannya akan tertuju pada satu kata, yaitu puisi. Chairil Anwar memang tidak bakal terpisahkan dari sastra Indonesia. Meski hidup singkat sebagai manusia,namun tidak sebagai seniman. Ia telah menggoreskan secara dalam pengaruhnya dalam persajakan modern Indonesia. Bahkan, napas Chairil Anwar dapat kita rasakan dalam persajakan Indonesia.

Biografi atau riwayat hidup adalah cerita tentang hidup seseorang yang ditulis oleh orang lain (sastrawan). Tugas penulis biografi adalah menghadirkan kembali jalan hidup seseorang berdasarkan sumber-sumber atau fakta-fakta yang dapat dikumpulkannya. Teknik penyusunan riwayat hidup itu biasanya kronologis: dimulai dari kelahirannya, masa kanak-kanak, masa muda, dewasa dan akhir hayatnya. Sebuah karya biografi biasanya menyangkut kehidupan tokoh-tokoh penting dalam masyarakat atau tokoh-tokoh sejarah (Sumardjo and Saini KM.).

\section{METODE}

Metode yang digunakan dalam penelitian adalah metode deskriptif karena penelitian ini hanya untuk melakukan hubungan antarvariabel, menguji hipotesis, mengembangkan generalisasi, mengembangkan teori yang memiliki validitas universal.

Penggunaan metode deskriptif dalam penelitian bertujuan untuk, menemukan realitas kehidupan yang terdapat dalam biografi
Chairil Anwar, serta mendeskripsikan kemampuan siswa dalam menemukan realitas kehidupan yang berhubungan dengan sikap serta perilaku terhadap diri sendiri, keluarga, serta masyarakat dan bangsa dari hasil membaca biografi Chairil Anwar.

Penelitian ini dilakukan dengan beberapa teknik. Adapun teknik penelitian yang digunakan dalam penelitian ini yakni teknik tes dan angket. Oleh karena itu, untuk memudahkan penelitian khususnya untuk mengumpulkan data serta informasi yang berkaitan dan mendukung dalam penelitian ini maka digunakan beberapa teknik penelitian yaitu sebagai berikut.

\section{1) Teknik Angket}

Teknik angket adalah suatu teknik yang digunakan untuk mengumpulkan data dan informasi dari sejumlah responden tentang hal-hal yang diketahuinya. Teknik ini dilaksanakan dengan cara menyebarkan sejumlah pertanyaan kepada responden untuk memperoleh data berupa pendapat responden. Jenis angket yang digunakan dalam penelitian ini berupa angket tertutup, yaitu tipe angket yang jawabannya sudah disediakan sehingga responden hanya tinggal memilihnya. Angket ini disebar kepada responden yang berjumlah 32 orang yang terdiri dari responden laki-laki berjumlah 23 orang dan responden perempuan berjumlah 9 orang. Hasil dari penggunaan teknik angket ini yaitu untuk mengetahui respon siswa terhadap biografi Chairil Anwar sebagai bahan pembelajaran sastra untuk siswa SMA.

\section{2) Teknik Tes}

Teknik tes adalah suatu teknik yang digunakan untuk mengetahui kemampuan seseorang. Dalam penelitian ini, teknik tes digunakan untuk mengetahui kemampuan siswa dalam menemukan realitas kehidupan dari hasil membaca biografi Chairil Anwar. Teknik ini dilakukan dengan cara memberikan lembar tugas (lembar kerja) yang berisi penugasan kepada siswa untuk mencari / 
menemukan realitas kehidupan dalam biografi Chairil Anwar. Tes yang digunakan dalam penelitian ini berbentuk tes tulis dengan bentuk soal uraian.

Prosedur penelitian dirancang dalam tiga tahap utama yang terdiri atas tahap perencanaan, tahap pelaksanaan pembelajaran (di dalamnya terjadi proses pengamatan), serta tahap analisis dan refleksi.

\section{1) Tahap Perecanaan}

Tahap perecanaan ini dilakukan meliputi peyusunan Recana Pelaksanaan Pembelajaran (RPP), penetuan biografi sebagai model, peyusunan instrumen penelitian yang diperlukan, serta penetuan kelompok siswa secara heterogen dengan data utama yang diperoleh dari guru mata pelajaran Bahasa Indonesia.

\section{2) Tahap Pelaksanaan}

Pada tahap ini meliputi pelaksanaan skenario pembelajaran oleh peneliti di kelas X IPS 5 semester 2, bagaimana proses pembelajaran berlangsung, disertai dengan kegiatan obserasi dan interpretasi serta diikuti kegiatan refleksi. Pada akhir tahap pelaksanaan tindakan pembelajaran ini akan diperoleh produk pembelajaran berupa Biografi.

\section{3) Tahap Analisis dan Refleksi}

Hasil yang diperoleh dari tahap pembelajaran dikumpulkan dan di analisis dalam tahap ini. Dari hasil pembelajaran tersebut guru dapat merefleksi dengan melihat data hasil analisis apakah kegiatan yang dilakukan telah meningkatkan partisipasi dan prestasi belajar siswa

\section{HASIL DAN PEMBAHASAN}

Berkaitan dengan tujuan penelitian, yaitu untuk mendeskripsikan realitas kehidupan pada biografi Chairil Anwar, ternyata berdasarkan deskripsi data dan analisis data yang ada yang merujuk pada teori pada bab sebelumnya, biografi ini mengandung realitas kehidupan yang meliputi sikap dan perilaku yang berhubungan dengan diri sendiri, sikap dan perilaku yang berhubungan dengan keluarga, serta sikap dan perilaku yang berhubungan dengan masyarakat dan bangsa. Berikut ini merupakan penjabaran dari hasil analisis tersebut.

Menemukan realitas kehidupan yang terdapat dalam biografi Chairil Anwar yang berjudul "Hari-Hari Si Penyair" yang berkaitan dengan realitas kehidupan erat dengan diri sendiri, di dalamnya terdapat sikap tekun, menpunyai tekad yang kuat dalam memperjuangkan hidup, selalu bersungguhsungguh dalam melakukan tindakan demi usaha yang maksimal.

Sikap dan perilaku hubungannya dengan keluarga dalam biografi ini yaitu selalu bersikap harmonis terhadap istri dan anaknya, memberikan semangat kepada mereka agar selalu yakin bahwa ia akan membahagiakan keluargnya, serta semangat dalam membaca dan belajar.

Sikap dan perilaku yang berhubungan dengan masyarakat dan bangsa dalam biografi ini yaitu, Sikap dan perilaku yang berhubungan dengan Masayarakat dan Bangsa yaitu ketika Chairil anwar yang tak bisa berhenti mengoceh tentang seniman-seniman Indonesia dan membeberkan semuanya kepada masyarakat mengenai perkembangan di Negara Indonesia yang berkaitan dengan para seniman.

Hasil kerja siswa dalam menemukan realitas kehidupan diperoleh dengan nilai tertinggi, nilai terendah dan nilai sedang. Nilai tertinggi kemampuan siswa dalam menemukan realitas kehidupan yaitu 85. Hal tersebut menandakan bahwa siswa kelas X IPS 5 SMA Pasundan 1 Cianjur berkemampuan baik dalam menemukan realitas kehidupan dalam biografi Chairil Anwar. Setelah dipersentasikan diketahui bahwa nilai rata-rata kemampuan menulis cerpen adalah 66. Apabila dihubungkan pada tabel penentuan patokan skala penilaian maka rata-rata nilai 
tersebut termasuk dalam kategori baik karena berada pada persentase 66\%-79\%. Hal ini berarti bahwa siswa kelas X IPS 5 SMA Pasundan 1 Cianjur baik dalam menemukan realitas kehidupan. Berdasarkan hasil analisis, dapat ditarik kesimpulan bahwa masih sedikit siswa yang mampu menemukan realitas dengan sangat baik. Sebagian besar dari mereka berada dalam kategori cukup. Hal ini tentu saja harus menjadi perhatian, agar kemampuan siswa dalam pembelajaran menemukan realitas kehidupan dapat lebih ditingkatkan.

Aktivitas pembelajaran dilakukan secara berkelompok yang terdiri atas 5-6 siswa setiap kelompok. Jumlah sampel kelas X IPS 5 adalah 32 orang, sehingga jumlah kelompok yang terdapat dalam kegiatan pembelajaran seluruhnya adalah 5(lima) kelompok. Terdapat satu kelompok yang mendapatkan nilai dibawah KKM yaitu 70 tetapi hanya mendapatkan nilai 60 karena pada kelompok tersebut hanya menunjukan poin-poin saja dan hanya sebagian kecil saja.

Hasil penilaian di atas melalui pembelajaran menemukan realitas kehidupan dalam biografi Chairil Anwar yang berhasil di temukan dan dicari oleh siswa berdasarkan 3 kriteria yang ditetapkan memperoleh rentang jumlah skor antara 70-85. Hasil perolehan jumlah skor tertinggi (85) didapat oleh kelompok 3, kemudian disusul oleh kelompok 1 yang memperoleh jumlah skor sedang yaitu (76), dan kelompok 2 mendapatkan nilai (60) skor terendah dan pada kelompok lainnya, yakni kelompok 4 yang memperoleh jumlah skor (74), kelompok 5 mendapat nilai (71). Kriteria ketuntasan minimum (KKM) yang dipersyaratkan pada kompetensi dasar "mengidentifikasi biografi dengan menemukan realitas kehidupan dalam biografi chairil anwar sesuai isinya adalah 70. Sehingga dapat disimpulkan bahwa proses pembelajaran yang dilaksanakan pada penelitian ini telah terlaksana dengan baik.

Pada saat siswa diberikan angket oleh guru dan diisi siswa, secara keseluruhan siswa merespon pelajaran Biografi sebesar 90\% artinya seluruh siswa dapat memahami apa yang dipaparkan oleh guru mengenai pembelajaran biografi. Angket yang diberikan tidak hanya mengenai Biografi melainkan tentang pembelajaran sastra atau bahasa Indonesia.

Angket yang diberikan kepada siswa, semata-mata tidak hanya untuk kepentingan kelengkapan setelah melakukan tes kepada siswa. Tetapi untuk mengetahui respon siswa terhadap pelajaran Biografi khususnya serta mengenai sastra dan juga bahasa Indonesia. Tertanyata dapat disimpulkan bahwa keseluruhan siswa dapat dikatakan baik dalam merespon atau mengisi angket yang telah diberikan serta siswa dalam merespon pelajaran biografi ternyata masih sangat diminati.

\section{PENUTUP}

Biografi Chairil Anwar merupakan sebuah kisah hidup yang mengungkapkan perjuangan sosok Chairil Anwar dengan realitas kehidupan. Di dalamnya terdapat perjuangan hidup dari mulai masa kecil, remaja, dewasa, menikah dan meninggal. Kehidupan yang berat ia harus jalani dengan ikhlas dan sabar.

Chairil sosok seorang yang tak mau menyerah dan terus berusaha dalam hidup terutama untuk keluarganya. Beliau mencari sesuap nasi untuk anak dan istri dengan bekerja tidak tetap. Banyak teman yang tak suka dengan kelakuan Chairil anwar yang kasar dan ceplas-ceplos. Tapi tidak ia dengar dan ia perdulikan. Tidak sedikit orang yang menyukai sosok

Chairil Anwar, terutama teman-temannya. Hanya teman dekat ia yang tahu bagaimana sikap dan perilakunya. Sudah taka sing lagi bagi mereka teman dekatnya dengan sikap chairil anwar yang seperti itu. Kehidupan yang sulit dan semakin ia tidak mempunyai uang untuk bertahan. Ia sering kali meminjam uang kepada temannya untuk membayarkan ia 
makan dan keperluan lainnya. Pakaian yang sudah kumal, bau, dan jorok tetap ia kenakan walau tak enak dilihat orang.

Tingkah laku yang ia punya membuat para temannya sudah biasa dan tetap ia temani. Ketika zaman semakin sini semakin banyak hujatan semakin banyak penolakan terhadap nya tapi tak ia masukan dalam hati. Ia tak pernah mengeluh dengan keadaan yang semakin rumit.

Berkaitan dengan realitas kehidupan yang terkandung pada biografi Chairil Anwar, sebagian besar berkaitan dengan sikap dan perilaku dalam hubungannya dengan diri sendiri. Realitas Kehidupan yang terdapat dalam biografi Chairil Anwar yang berjudul "Hari-Hari Si Penyair" yang berkaitan dengan sikap dan perilaku terhadap diri sendiri erat dengan kehidupan sehari-hari, di dalamnya terdapat sikap tekun, menpunyai tekad yang kuat dalam memperjuangkan hidup dan citacita, dan selalu bersungguh-sungguh dalam melakukan tindakan demi usaha yang maksimal.

Realitas Kehidupan yang terdapat dalam Biografi Chairil Anwar yang berkaitan dengan Sikap dan perilaku yang berhubungan dengan keluarga yaitu ketika Chairil Anwar yang tak bisa diam dalam satu pekerjaan, dia memiliki sifat yang keras untuk menghidupi istri dan anaknya serta kebutuhan dapur. Tidak hanya itu, tapi Chairil sangat sayang terhadap anaknya ketika ia melihat suatu kondisi anaknya yang semakin berkembang tapi ia belum bisa jalan.

Realitas Kehidupan yang terdapat pada biografi ini berkaitan dengan Sikap dan perilaku yang berhubungan dengan Masyarakat dan Bangsa yaitu ketika Chairil anwar yang tak bisa berhenti mengoceh tentang seniman-seniman Indonesia dan membeber- kan semuanya kepada masyarakat mengenai perkembangan di Negara Indonesia yang berkaitan dengan para seniman.

Berkaitan dengan kemampuan siswa dalam menemukan realitas kehidupan dalam Biografi Chairil Anwar, hasil tes menunjukkan rata-rata 66. Apabila dikonsultasikan pada tabel skala penilaian maka rata-rata nilai tersebut termasuk kategori baik karena berada pada angka 66-79. Hal ini berarti bahwa siswa kelas X IPS 5 SMA Pasundan 1 Cianjur baik dalam menemukan realitas kehidupan Biografi Chairil Anwar.

Dengan adanya penelitian ini diharapkan guru bidang studi bahasa Indonesia dapat lebih memperkaya bahan ajar siswa dibandingkan dengan yang sudah ada. Sebagai sumber bahan ajar bukan hanya buku-buku paket saja yang dijadikan acuan untuk proses belajar, tetapi lebih baik jika guru bidang studi bahasa Indonesia dapat menggunakan sumber bahan ajar lain baik biografi, ataupun karya sastra lainnya yang sedang hangat atau baru muncul. Saran lainnya bagi guru bidang studi bahasa Indonesia, guru perlu mengkolaborasikan metode dan teknik belajar, sehingga pembelajaran sastra tidak bersifat monoton atau tidak membuat siswa merasa jenuh dan bosan.

Saran untuk siswa yaitu agar lebih meningkatkan kegemaran membaca dan menganalisis. Karena dengan banyak membaca bisa membuka wawasan dan pengetahuan semakin banyak, dengan sering belajar mengenai biografi bakat siswa akan terlihat, dari mencoba mungkin akan dapat menghasilkan siswa menjadi lebih tahu yang asalnya tidak tahu menjadi tidak tahu.

\section{DAFTAR PUSTAKA}

Agustina, Niki. "Improved Ability To Analyze Short Stories With Discovery Learning Model." Alinea: Jurnal Bahasa, Sastra, dan Pengajaran, vol. 7, no. 1-6, 2019. 
Laila, Azah Nur, and Widodo Budhi. "Pengaruh Model Pembelajaran Discovery Learning Terhadap Prestasi Belajar.” Jurnal Ilmiah Pendidikan Fisika, vol. 4, no. 2, 2017, pp. 57-64.

Mahdi, Imam, et al. "Metode Discovery Learning dalam Pembelajaran Sejarah Khulafaurrasyidin.” Edukasi Islami: Jurnal Pendidikan Islam, vol. 8, no. 01, 2019, pp. 143-58, doi:10.30868/ei.v8i01.357.

Muslim, Siska Ryane. “Kontribusi Penggunaan Model Discovery Learning Terhadap Kemampuan Berpikir Kreatif Matematik Peserta Didik." Jurnal Penelitian Pendidikan dan Pengajaran Matematika, vol. 2, no. 1, 2016, pp. 67-74.

Novita, Fidya, et al. "Peningkatan Aktivitas dan Hasil Belajar Tematik Melalui Model Discovery Learning Dengan Pendektan Saintifik Di SD.” Diklbio: Jurnal Pendidikan dan Pembelajaran Biologi, vol. 2, no. 2, 2018, pp. 86-93.

Sanjaya, Wina. Strategi Pembelajaran Berorientasi Standar Proses Pendidikan. I, Kencana Prenada Media, 2011.

Sumardjo, Jakob, and Saini KM. Apresiasi Kesusastraan. Pustaka Prima, 1988. 